\title{
The link between demography and labour markets in sub-Saharan Africa
}

Evert-jan Quak

Institute of Development Studies (IDS)

20 January 2021

\section{Question}

What can the literature tell us about the channels through which the demographic transition in sub-Saharan Africa could affect the labour market and vice versa?

- How do demographic trends in sub-Saharan Africa affect the labour market (e.g. entrants, including youth and women) and labour market outcomes (e.g. capital-perworker, life-cycle labour supply, human capital investments).

- How labour market outcomes could affect population dynamics in sub-Saharan Africa?

\section{Contents}

Key findings

1. Summary

2. Projected changes in the African population and labour force

3. How does population growth affect labour markets and their outcomes?

4. How and when a fertility decline impacts on labour market

5. Understanding behavioural implications

6. Using macro-simulation models

7. References

The K4D helpdesk service provides brief summaries of current research, evidence, and lessons learned. Helpdesk reports are not rigorous or systematic reviews; they are intended to provide an introduction to the most important evidence related to a research question. They draw on a rapid deskbased review of published literature and consultation with subject specialists. 


\section{Key findings}

- The population of Africa is projected to double from 1.2 billion in 2020 to 2.4 billion by 2050 (Population Council, 2020). Sub-Saharan African countries face the highest working-age population growth in the world with the working-age population estimated to more than double between 2020 and 2050.

- Sub-Saharan Africa's lack of structural transformation significantly limits the ability to absorb all new entrants into the labour market. This has resulted in an 'underemployment' crisis in most of the region, characterised by low quality and productivity work.

- Importantly, there is evidence that population growth itself is a barrier to accomplish a structural transformation of the labour force towards higher labour productivity. A large youth cohort lowers output-per-worker, because investments in physical and human capital struggle to outpace the growing population.

- An accelerated demographic transition would increase the share of working-age population, creating a 'window of opportunity'. However, such change in age structure only generates long-term labour market outcomes if accompanied with strong investments in human capital.

- If a country prioritises economic (e.g. investment in productive sectors), social (e.g. gender equality), and demographic (e.g. family planning) interventions, productivity growth, higher incomes and per capita GDP could increase significantly, initiated by lower fertility.

- However, in the sub-Saharan African context, no significant savings effect should be expected from fertility declines. The capital per worker is not expected to increase substantially in the next decades. Savings will stay low for a longer time until real wages and incomes rise significantly.

- The biggest gains come later, due to multiplier effects of greater investment in physical and human capital, particularly girls' education. This implies changes of behaviour due to higher life expectancy and women participation in the workforce, reinforcing low fertility. 


\section{Summary}

This rapid review synthesises the literature from academic, policy, and knowledge institution sources on how demography affects labour markets (e.g. entrants, including youth and women) and labour market outcomes (e.g. capital-per-worker, life-cycle labour supply, human capital investments) in the context of sub-Saharan Africa. It concludes that:

- The current high fertility rate (declining but at a slow pace) generates large youth cohorts in rural and urban settings, increasing the challenge to absorb new entrants into the labour market.

- Large youth cohorts are a barrier to increase productivity in labour-intensive sectors, because keeping up with the current level of output per worker requires a significant increase in capital investment each year. This affects the majority of low-educated workers (men and women) the most, who over their life cycle continue to struggle to increase their productivity, keeping them in low paid, insecure jobs.

- Fortunately, there is increasing evidence from economic demography literature that there are different channels out of this scenario of high fertility, low productivity, and low incomes.

Box 1: Demography is an important factor for analysing labour market dynamics in sub-Saharan Africa in two ways.

- There is an urgent need to understand how the demographic transition, resulting in high numbers of new entrants in the labour market year after year, affects labour market outcomes now and in the future.

- It is important to understand how a potential accelerated demographic transition towards lower fertility (driven by voluntary family planning, girls' education, political leadership) could impact on the labour market and labour market outcomes.

The fast-growing population in sub-Saharan Africa is likely to affect the ability to get productive jobs and in turn economic growth. This normally happens when workers move from traditional (low productivity agriculture and household businesses) sectors into higher productivity sectors in manufacturing and services. Another way is to increase productivity within the traditional sectors. Key for both is technological change that complements the labour force (instead of displacing them) and better skill levels to adapt to technological change. This implies human and physical capital investments, which for a large part need to come from domestic savings. However, the current high fertility and low-income scenario in sub-Saharan Africa makes it difficult to significantly increase savings levels at the household level and public level.

In theory the literature shows that lower dependency ratios (share of the non-working age population) should increase output per capita if labour force participation rates among the working age population remain unchanged. If output per worker stays constant, then a decline in dependency ratio would lead to a rise in income per capita. Macro simulation models for subSaharan Africa estimate that capital per worker will remain low due to consistently low savings for at least the next decades, even in the low fertility scenario. Sub-Saharan African countries seem too poor for a quick rise in savings. As such, it is unlikely that a lower dependency ratio will initiate a dramatic increase in labour productivity. There is evidence, 
however, that a change in age-structure will slightly increase incomes and consumption levels, which could be indirectly beneficial for local economic development and job creation.

The main gains come over a longer period, induced by changing behaviour (driven by investments for higher life expectancy and women's participation in the labour market), which relate to feedback loops that could further reduce fertility rates and increase productivity for the next generation. As a result, higher income could finally trigger a surge in household savings over time (the life cycle effect), giving incentives for more investment and higher capital per worker. However, if a smaller youth cohort does not receive significant investment in human capital, this benefit will fade away over one generation, reducing the opportunity of a pathway to higher productivity and capital per worker.

Box 2 is a summary of various labour market effects, induced by population dynamics, to which this report refers in different ways. In general, the literature concludes that the dependency effect of economies with an increasing working-age population from an accelerated demographic transition, does not automatically instigate the life-cycle effect and experience effect of higher savings and productivity. Without the right public and private investments these countries will continue to struggle to increase output, increased incomes, and better-quality jobs. Fertility induced increases in GNP per capita, therefore, should (at least partially) be reinvested in the human capital of future workers.

Box 2: Different ways to look at labour market effects induced by population dynamics:

- Malthus effect: Population expansion results in congestion of fixed factors of production.

- Solow effect: High growth in labour force leads to lower capital per worker.

- Dependency effect: Reduction in fertility leads to higher share of working-age population.

- Life-cycle effect: Higher share of working-age may raise national savings rates.

- Experience effect: Increase in average experience raises average productivity.

- Life-cycle labour supply effect: Higher participation rates at higher average age.

- Childcare effect: Lower time devoted to childcare frees up time for productive labour.

- Child-quality effect: Lower fertility increases investments in education per child.

- Health-improvement effect: Lower fertility increases investments in health per child.

- Boserup effect: Population pressure encourages intensification or innovation.

- Endogenous feedback effect: Fertility falls further in response to improving socioeconomic conditions.

It is important to understand gender implications. Most women combine unpaid care for children with informal and low productive work in agriculture or family enterprises. Large family sizes reduce their productive labour years significantly, estimated at a reduction of 1.9 years of productive participation per woman for each child (Bloom et al., 2009). This complicates their move into more productive work (if available). If the transition from high fertility to low fertility is permanent and can be established in a relatively short-term period, there are long-run effects on female labour participation, and the gains in income per capita will be permanent. As such from the literature it is clear that the effect of higher female wages on female labour participation works to a large extent through reductions in fertility. 


\section{Projected changes in the African population and labour force}

- The population of Africa is projected to double from 1.2 billion in 2020 to 2.4 billion by 2050 (Population Council, 2020).

- Sub-Saharan African countries face the highest working-age population growth in the world with the working-age population estimated to more than double between 2020 and 2050.

- Annual growth rate of sub-Saharan Africa's working-age population set to peak at around $3 \%$ per year around 2025, but in absolute terms it will reach a peak of 2.3 million new entrants a month in 2055 (Lam et al., 2019).

- While sufficient jobs have been created to keep up with population growth, particularly in the informal sector, the real challenge is an 'underemployment' crisis.

- Agriculture and household enterprises together make up around $85 \%$ of the workforce in subSaharan Africa and often act as a 'last resort' employment destination.

- In sub-Saharan African countries women experience high time-related underemployment as they have to combine work with unpaid household and care work.

- The share of rural population is projected to fall below $50 \%$ by 2036 , however, the rural population is projected to increase in absolute numbers by $40 \%$ from 2020 to 2050 . Hence, sub-Saharan Africa faces fast urban growth while still considering a growing rural population.

\section{Population dynamics}

The population of Africa is projected to double from 1.2 billion in 2020 to 2.4 billion by 2050 (Population Council, 2020). The total African population could account for $26 \%$ of the world's total by 2050 and $40 \%$ of by 2100 , becoming the most populous region in the world around 2062 (UN DESA, 2019). While most of the rest of the world faces an aging population, sub-Saharan Africa's average population is getting older at a much slower rate. For example, the number of 15- to 24-year-olds is expected to increase by $80 \%$ between 2020 and 2050 (Lam et al., 2019). Such young age structures mean that populations will continue to grow for some time, even after attaining replacement level fertility.

It is important to highlight that most sub-Saharan African countries are actually in the process of a demographic transition in which mortality and fertility rates decline.

Projections of future fertility declines in sub-Saharan Africa vary but nearly all forecasts predict that fertility will continue to decline in the coming decades, but still at a slower pace relative to declines in Asia and Latin America (Bongaarts et al., 2020). The total fertility rate (TFR) in subSaharan Africa is 4.8 births per woman (Beegle \& Christiaensen, 2019). Therefore, Bongaarts et al. (2019: 9) conclude: "Elevated fertility, coupled with further declines in mortality, will lead to continuous population growth in sub-Saharan Africa throughout the remainder of this century". 1 See more on population dynamics in Annex 1.

\section{Labour force dynamics}

Most of the world's working-age population growth is concentrated in sub-Saharan Africa, with the working-age population (aged between 15-64) estimated to more than double

\footnotetext{
${ }^{1}$ High demand for children and unmet need for effective contraception among women who do not want a child soon or want no more children are both factors that sustain high fertility in Africa (Casterline \& Agyei-Mensah, 2017).
} 
between 2020 and 2050 (with the exception of Southern Africa), while in Asia and Latin America it will only increase by around $10 \%$ in this same period (Lam et al., 2019). Most countries in Central, Eastern, and Western Africa will have increases in their working-age population of $30-40 \%$ in the next 10 years alone. ${ }^{2}$

The African Development Bank estimated that 10 to 12 million young people enter the labour market each year, with only 3.1 million new formal jobs being created (AfDB, 2016). Lam et al. (2019) calculated that this number of entrants has increased, now adding over 1.5 million people per month. Peak annual growth rate is estimated at $3 \%$ in 2025 and will remain high for many decades - although declining throughout the century. As a result, the absolute number added to the working-age population, will continue to increase, reaching 2 million per month in 2037 and peaking at 2.3 million per month in 2055 (Lam et al., 2019). The size of the working age population compared with the total population (working-age population share) is expected to increase significantly in African countries during this century, while regions outside Africa will see a decline of this share.

See: Figure 1. Share of population under age 18 (left) and share of population aged 18-64 (right), Source: UN Population Division 2019 (cited from Bongaarts et al., 2020: 9),

https://knowledgecommons.popcouncil.org/cgi/viewcontent.cgi?article=2183\&context=departments_s bsr-pgy

Another measure that is often used by demographers is dependency ratios; the size of the population outside the labour market (children aged $<15$ and older people aged $>65$ ) compared with the size of the working-age population. As such, dependency ratios are often separated in a child dependency ratio and an elderly dependency ratio. Data shows that dependency ratios in Africa are evolving differently in comparison to other regions in the world. In 2020, the total dependency ratio is high and declining in sub-Saharan Africa. The total dependency ratio is expected to continue to fall in sub-Saharan Africa over the next decades till 2070, due to the high but slowly declining child dependency ratio (which relates to high but declining fertility rates) and still low elderly dependency ratio. In contrast, the total dependency ratio in Asia and Latin America will increase throughout this century triggered by a rapidly increasing elderly dependency ratio.

See: Figure 2: Dependency ratios, Source: Lam et al. (2019: 38), https://g2lm-lic.iza.org/wpcontent/uploads/2019/11/glmlic_sp010.pdf

The major task for sub-Saharan African countries is to create enough jobs for its growing population. Overall, the unemployment rate in Africa is 4.3\% (ILO, 2019). For young people (15-

24 years old), unemployment rates are about twice as high as adults in sub-Saharan Africa (Baah-Boateng, 2016) and 3.5 to four times higher in Northern Africa (Baah-Boateng, 2016; ILO,

\footnotetext{
${ }^{2}$ The working-age population in the region is projected to increase by $34 \%$ by 2030 , by $118 \%$ by 2050 , and by $307 \%$ by 2100 (Lam et al., 2019).
} 
2019). ${ }^{3}$ That total unemployment and youth unemployment rates are low for sub-Saharan Africa (with the exception of South Africa) masks the real challenge for the vast majority of the labour force: that of an 'underemployment' crisis, along with working poverty and vulnerability (Meagher, 2016; Quak \& Flynn, 2019). ${ }^{4}$ People simply cannot afford not to work (Fox \& Thomas, 2016; ILO, 2019) pushing the 'employed' into low-productive, insecure work

often in the informal sector where conditions are generally very poor. It is estimated that $86 \%$ of employment is informal in Africa (ILO, 2019), mainly concentrated in Western, Central and Eastern Africa. Thus, the often mentioned 'youth employment crisis' in Africa is more a problem of underemployment rather than unemployment in most subregions. ${ }^{5}$

This is in line with analysis of the labour market in sub-Saharan Africa by Abdychev et al. (2018). Their study shows that sub-Saharan African countries might have created sufficient jobs to keep up with population growth over the past two decades and could continue to do the same in the next decades; however, quality did not accompany quantity, with most of the new jobs created in agriculture or services with low value added and in vulnerable self-employment roles.

See: Figure 3: Employment and population growth in sub-Saharan Africa, Source: Abdychev et al. (2018: 6), https://www.imf.org/en/Publications/Departmental-Papers-PolicyPapers/Issues/2018/12/14/The-Future-of-Work-in-Sub-Saharan-Africa-46333

Fox and Thomas (2016) find that those working in the informal sector essentially work in one of two types of work: agriculture and household enterprises, which together make up around $85 \%$ of the workforce in sub-Saharan Africa. Agriculture, including household enterprises with links to agriculture, are often a last resort employment destination for many in sub-Saharan Africa. This is also reflected by a sustained total rural population, which declines in almost every part of the world except from sub-Saharan Africa. Sub-Saharan Africa is still 59\% rural, though the share of rural population is projected to fall below $50 \%$ by 2036 (Lam et al., 2019). According to Lam et al. (2019) the rural population is projected to increase in absolute numbers by $40 \%$ from 2020 to 2050 . Hence, although urban growth will be much faster, projected to increase by $170 \%$ from 2020 to 2050, sub-Saharan Africa will still have a large and growing rural population to consider.

According to Sunmola et al. (2020) gender-equality in employment remains one of the greatest development challenges in labour markets globally. In some countries in sub-Saharan Africa,

\footnotetext{
${ }^{3}$ Youth unemployment rates are around $11.6 \%$ for SSA (ILO, 2015), whilst in Northern Africa they are the highest in the world and expected to exceed 30\% in 2019 (ILO, 2019), and in Southern Africa's middle-income countries (MICs), youth unemployment rates are typically above $20 \%$.

${ }^{4}$ According to the AfDB (2016: 120), Southern African middle-income countries "face the challenge of high unemployment among low-skilled workers", where young people are more highly represented, whereas Northern Africa is more characterised by "educated unemployment". Another difference between sub-Saharan Africa and Northern Africa is that wage and salaried work accounts for $68.6 \%$ of total employment in Northern Africa, while it only represents $22.4 \%$ of employment in sub-Saharan Africa (ILO, 2019).

${ }^{5}$ The literature also refers to 'vulnerable employment', which is work based on "short term or no contracts", and therefore also associated with less or no access to social protection, benefits, and more exposure to risk from economic cycles. At $77 \%$ of those in employment, sub-Saharan Africa has the highest level of vulnerable employment in the world (sources from ILO and AfDB, as cited in Quak \& Flynn, 2019).
} 
time-related underemployment for women is as high as $\mathbf{4 0}$ or $\mathbf{5 0 \%}$ of total employment while women continue working fewer hours in paid employment and still perform the vast majority of unpaid household and care work, often the result of persisting gender norms (Sunmola et al., 2020). In sub-Saharan Africa, many working women remain self-employed and a high proportion work as contributing family workers, mainly in the food economy (34.9\%) (Allen et al., 2018). In sub-Saharan Africa, $63.2 \%$ of women in wage employment do not contribute to social protection and therefore cannot fall back on a social safety net - globally this number is $40 \%$ (Sunmola, 2020).

\section{How does population growth affect labour markets and their outcomes?}

- A lack of structural transformation in the economies of sub-Saharan African countries limits opportunities to create enough jobs for the rising working-age population. Even under the most favourable projections, only about a quarter of the people newly entering the labour force will find wage employment in the formal economy (Jayne et al., 2017).

- The projection of new jobs in agriculture is not based on demand for labour in the sector, like in other sectors, but represents the part of the labour force that cannot find a wage job or start a business.

- Labour productivity growth is only at $0.6 \%$ per year in sub-Saharan Africa (ILO, 2019). High population growth slows the effect of productivity growth effort because the stock of capital (both human and physical) must continually increase just to maintain capital per worker and current productivity.

- For sub-Saharan Africa there is not sufficient evidence to claim that low productivity at job entry level increases sufficiently in a lifetime. If a youth cohort does not receive better education combined with a higher capital-labour ratio approach to stimulate economic development, they remain dependent on low-quality, low-productivity work.

- High population growth has direct implications for gender equality. For women, high fertility rates reduce their productive years of labour. Each birth reduces total labour supply by about 1.9 years per woman (Bloom et al., 2009).

\section{Demography and structural transformation}

The influence of demographic indicators such as life expectancy and fertility on economic growth and development has led several economists to consider them as endogenous variables in their models. If the aim of African countries' economic development is to create continuously more and better jobs for the expanding labour force, they need a structural transformation of their economies and labour force (Maghimbi, 2020). The transition from low to higher productive sectors and businesses has historically resulted in greater job specialisation, more jobs, and rising incomes. When this happens a certain level of population growth could be accommodated or even raise working and living standards, because population growth could stimulate demand, encourage technological innovation, and reduced investment risks (World Bank, 1984). When this happens, often in combination with extra spending on education, this could result in continuous upgrading of the labour force with better educated workers and lower youth unemployment (Maghimbi, 2020).

However, the literature on sub-Saharan Africa is clear that this does not apply to the region, due to two reinforcing factors: 
- A weak structural transformation cannot support the population growth: The current economies of most sub-Saharan African countries are struggling to adapt to the rapid increase in the labour force, resulting in the problem of underemployment and of high numbers in low value adding jobs (this section, which relates to what is called the Malthus effect).

- High population growth obstructs structural transformation: The literature emphasises that a prolonged phase of high population growth itself is an important barrier to achieve a structural transformation by increasing the capital-labour ratio (see more in the next section on productivity, also referred to as Solow effect).

In theory, some African countries with untapped natural resources could support more people. However, rapid population growth makes it hard for them to develop the human skills and administrative structures that are needed to exploit their resources (World Bank, 1984). On the other hand, most countries have limited exploitable resources, particularly for agriculture expansion, relying mainly on growth in agricultural production (productivity) and the expansion of manufacturing industry. Both solutions require costly investments, development of new institutions, and numerous economic and social adjustments all easier with moderate population growth (World Bank, 1984).

Evidence from Fox et al. (2013: 7) suggests that there are speed limits with which the manufacturing and service sectors can absorb new workers: "The lack of demographic transition [in sub-Saharan Africa] complicates the employment transformation, because even with non-agricultural private sector enterprise growth as rapid and labour intensive as occurred in the last 20 years in East Asia, a similar employment transition [towards non-farm wage jobs] could not occur". Although economic growth has been very strong in many sub-Saharan African countries over the past decades, the literature does not show a significant change in output share of industry or in the export share of manufacturing products, including food manufacturing (Fox et al., 2013).

Even under the most favourable projections, only about a quarter of the people newly entering the labour force will find wage employment in the formal economy (Jayne et al., 2017). As Jayne et al (2017) mention, some literature shows that the agriculture sector in subSaharan Africa is able to absorb (at least some of) these levels, since about $70 \%$ of those who are expected to exit the labour force due to high age are now working in agriculture. However, crunching the numbers, Jayne et al. (2017) show that the actual number of new entrants that the agricultural sector needs to absorb, is over 62 million in sub-Saharan Africa (or about $38 \%$ of the expected new entrants) over the next ten years; this is far more than the number to replace the older generation of farmers during the same period. Stronger growth in other sectors could push this number down slightly, but as Filmer and Fox (2014) show, it is unlikely that the labour force in agriculture will shrink over the next decade. This is because, unlike other sectors in lowand middle-income countries, the projection of new jobs in agriculture is not based on demand for labour in the sector, but represents the part of the labour force that cannot find a wage job or start a business (which relates to the two reinforcing factors as mentioned above).

Hence, Brooks (2018) states that it is normal for sub-Saharan African countries that the agricultural labour force is rising in absolute terms, while its share declines (compared to the labour force in other sectors). "An absolute net flow of labour out of agriculture would be 
extraordinary given the size of the agricultural labour force relative to the receiving sectors of services, construction, manufacturing and mining. Even as these sectors grow and absorb labour, they are not yet large enough to support a net reduction in the agricultural labour force, particularly with the prevailing persistent high birth rates" (Brooks, 2018: 184).

This does not mean that there is no sign of agricultural transition in sub-Saharan Africa. The data show that the majority of small-scale farmers do not benefit from current commercialisation trends in agriculture (such as in Asia) (Reardon et al., 2018). On top of that, sub-Saharan African countries face a double challenge of providing productive employment for rapidly increasing numbers of urban dwellers in combination with absorbing challenges of a continuing increasing rural population (Lam et al., 2019). Box 3 shows some factors that could influence the structural transformation in sub-Saharan Africa and as such affect job opportunities for the growing labour force.

Box 3: Factors to consider regarding structural transformation of the economy in sub-Saharan Africa

- The cost of withdrawing labour from agriculture seems to have increased over time around the world (Timmer \& Akkus, 2008). Over the past 50 years, the point at which wages in agriculture converge with those in non-agricultural jobs has been reached at later stages in the transformation of successful economies, suggesting that "globally industry is becoming less and less able to absorb labour" and therefore manufacturing could become less important for the structural transformation of sub-Saharan Africa than it was for other regions (Filmer \& Fox, 2014, p.117).

- The required expansion of farm size to increase yields and productivity could displace labour precisely when demography requires agriculture to absorb labour. In parts of the world where farms have expanded from very small (two hectares and less) to mid-size holdings (5-100 hectares), labour has often been displaced (Filmer \& Fox, 2014). If farm size grows through consolidation of land that is already farmed and is accompanied with a reduction in the cost of mechanisation, then bigger farms could be expected to displace labour. However, the literature shows that conditions in Africa offer opportunities for simultaneous increases in average farm size and in employment (Lowder et al. 2016; Jayne et al., 2017).

- Urbanisation could create opportunities in non-farm employment in low- and middleincome countries. Increasing overall populations, higher urbanisation levels, income growth, and more women working outside the home in urban and rural areas all give rise to a potential increase of the economic potential of food systems (Quak \& Woodhill, 2018). Urbanisation means that households increasingly rely on markets and look for foods that are more diverse and convenient to buy, prepare, and consume. This transformation in local diets cuts across all countries and income groups and involves a move towards increased consumption of highervalue perishable and processed products (Allen \& Heinrigs, 2016; Staatz \& Hollinger, 2016).

- In the literature there is also a focus towards service sector development, which could link with some industrial clusters. However, high productivity and tradable services, such as finance and insurance, only attract high-skilled workers and so cannot absorb labour in the way that manufacturing has in the past. The bulk of the service sector is low productivity and nontradable work, for example cleaning and security services. It generates jobs, but they are not economic growth poles and therefore, this falls short as an alternative driver of economic transformation (Rodrik, 2016). Thus, authors like Losch (2016), Rodrik (2016) and Fox and Thomas (2016) recognise that poor employment outcomes are largely down to a lack of structural transformation in sub-Saharan Africa, which hinders, according to Fox et al. (2016), a rise in labour demand although labour supply continues to increase. 
Hence, projections for the region indicate that the labour force in agriculture is unlikely to shrink significantly over the next decade in sub-Saharan Africa as the service and manufacturing sectors are not predicted to absorb the new entries to the labour market (Losch, 2016). The slow pace of demographic transition and prevailing low educational and skill levels among a large portion of Africa's expanding labour force imply that a rapid transition into wellpaying formal wage jobs in the off-farm sector in the near future is not likely.

Consequently, most new entrants to the labour market are more likely to end up working in informal enterprises, whose growth is highly dependent on multiplier effects from agricultural growth.

\section{Demography and labour productivity}

The literature shows that productivity (output per worker) is key to understanding the link between structural transformation in sub-Saharan Africa and population growth and vice versa. The ILO (2019) finds that labour productivity growth is only at $0.6 \%$ per year in subSaharan Africa, and 2.5\% in Northern Africa (which is still below the 3.1\% registered in the rest of the world for 2018). They conclude that "[u]ltimately, labour productivity growth is expected to remain too slow and population growth too fast to allow African countries either to reduce poverty rapidly or to increase average incomes [Cilliers, 2018]." (ILO, 2019: 29). In countries with growing labour forces, the stock of capital (both human and physical) must continually increase just to maintain capital per worker and current productivity (also referred to as the Solow effect). When countries are not able to do so, each worker will produce less using the reduced land and capital each has to work with. Productivity, and thus incomes, will then stagnate or even fall. When real wages fall combined with higher profits and rents for a small elite, this will increase inequalities. See Box 4 about the debate to focus or not on productivity growth in the context of sub-Saharan Africa.

The total factor productivity growth can increase through a structural transformation through a transition of labour to manufacturing and higher end service sectors. However, as has been shown in the section above, this structural transformation has been challenged in the African context where the industry and services sectors are characterised by relatively low productivity and high informality which has lowered their average productivity and supressed the gains to be exploited from agricultural exits (Rodrik, 2016). Therefore, sub-Saharan Africa's prospect of higher productivity is mostly related through better performing businesses mainly in agriculture where rapid structural transition does not necessarily take place.

Box 4: The pros and cons of a focus on productivity growth in sub-Saharan Africa

Labour productivity is often used as a measure for more and better-quality and higher paid jobs (e.g. ILO decent work strategy) as labour productivity growth underpins rising per capita income. In these contexts, Bennell (2007) states that "[i]ncreasing productivity is at the centre stage for any strategy to increase the quality of employment (see Godfrey, 2005 and 2006)" (p.6). This also reflects a review by Basnett and Sen (2013), which found that an increase in agricultural output (ceteris paribus) will likely reduce underemployment (rather than creating new jobs, since overall unemployment is low in these contexts). Hence, productivity growth that occurs in the context of high unemployment and underemployment and a focus on rising capital intensity, could result in a slower or even falling growth of employment, especially for the relatively unskilled. Therefore, some scholars challenge the ILO's focus on productivity growth as a determinant for decent work. They emphasise that what sub-Saharan African countries mostly need is more jobs in 
labour-intensive sectors. This might not generate labour productivity gains in the short-term (Nattrass \& Seekings, 2017), but is necessary to absorb the increasing number of new entrants to the labour market.

Importantly, there is clear evidence that a large youth cohort results directly and indirectly in lower output-per-worker, which could undermine pathways to increase productivity within a sector or across sectors. This is particularly true when investments in agriculture are low and in the context of lower levels of education of the labour force. Most studies show (e.g. Shafii et al., 2016) that countries with high dependency ratios need to spend a large proportion of their economic resources on taking care of 'inactive' people, while those with lower ratios are able to devote more resources to investing in technological progress, physical and human capital which are all important determinants of labour productivity. These studies also suggest that child dependency has a more adverse impact on economic growth and productivity (measured as total factor productivity) than old age dependency, because the elder group have already contributed to their own support or remain active in the labour market even after their retirement.

Choudhry et al. (2016) empirical analysis indeed provides evidence that the age composition of the population matters. Higher age dependency negatively impacts on labour productivity growth not only directly but also indirectly, they conclude. The marginal effects of gross capital formation, labour market reforms, and ICT investment on labour productivity growth are significantly higher at lower levels of age dependency. As low-income countries have 1.9 times higher age dependency than high income economies, mainly concentrated in child dependency, this helps to explain labour productivity differentials among them (Choudhry et al., 2016).

Frini and Jedidia (2018) mention that the literature that looks at productivity differentials in the age structure of the labour force (so not of the total population) has a strong bias on high-income countries. These studies agree that labour productivity is low for the entrants to the labour force and that productivity will increase over the worked years (labour cycle). However, when and if the productivity will reduce at higher age is contested (Frini \& Jedidia, 2018). This is referred to in the literature as the experience effect. Although most of these studies are preoccupied with an ageing work force, and do not focus on sub-Saharan Africa, the takeaway for African countries is to understand how the high proportion of young labour entrants each year with low productivity levels will influence productivity growth pathways when they get older and what is needed to change this. In general, the conclusion now is that current population growth and increase in labour force is an important barrier for productivity growth at entrants' level, but also during the labour cycle, due to the lack of productive investments per capita.

\section{Technological change, education, savings, and open markets}

To understand how this persistent low productivity threat of a young population can be turned into productivity growth pathways depends largely on indicators, such as technical change, education, and integration in the world economy. On top of that, this implies building capacities and institutions. Countries cannot rely completely on foreign investment; therefore, they need domestic savings and domestic investment. To summarise, an increase in the aggregate size of the labour force can reduce the amount of available land and capital stock per worker, thereby lowering productivity. In the long run, a shortage of capital can be corrected by private and public investment, for example to be used for technological 
innovations. In addition, if the size of a youth cohort affects its educational attainment, as they receive fewer resources for schooling per pupil, this may adversely affect its productivity when the cohort enters the labour force.

\section{- Technological change:}

Demography is an important factor in how technological change affects labour markets. Where most other regions face technological change and automation at a time of ageing or even declining working populations, sub-Saharan Africa faces the challenge of a rapidly growing working population (with the need of adding a high number of new jobs to their economies each year for decades to come), while technological change has a potential threat to replace labour (Abdycheve et al., 2018). For subSaharan Africa, studies point to a large but uncertain impact of technological change and automation on jobs. McKinsey Global Institute (2017) and the World Bank (2016) did estimations for some sub-Saharan African countries. Both conclude that the impact will be less compared with advanced economies as labour costs remain low. However, the impact could still sizable, with estimates for individual countries in the region ranging from $40 \%$ to $60 \%$ of potential job losses.

On a positive note, Abdychev et al. (2018) mention that it will be more likely that technological change in sub-Saharan Africa complements labour rather than to completely substitute it. Sub-Saharan Africa as a region has the potential to gain because it has lower wages (due to low productivity and large youth cohort in labour force) and that makes it more profitable to invest in technology that complements relatively cheap labour. The relevance of technology as a substitute to large numbers of the African labour force would only be beneficial for high wage sections of the labour force (Abdychev et al., 2018). In the scenario that technological change indeed complements labour, productivity growth could result in higher real wages and better work conditions, also increasing the overall labour share, which is important to absorb new entrants to the labour market (Abdychev et al., 2018). However, depending on technological adaptation levels in sectors and regions within countries, this could result in higher inequalities.

\section{- Education:}

Productivity not only refers to more capital investments, but also to the availability of skilled labour. Skilled Biased Technological Change (SBTC) requires more and more skilled workers for the use of new production techniques, at least during adjustment processes. It consequently results in increased demand for skilled workers with higher wages. However, because countries in sub-Saharan Africa often lack the skilled workers necessary for the efficient utilisation of these technologies, there is a possibility that this could reduce the positive impact that these countries might obtain from a relatively young labour force (Hanushek \& Woessmann, 2012; Abdychev et al., 2018). ${ }^{6}$

\footnotetext{
${ }^{6}$ The technology/skill mismatch consequently could result in continuing low productivity, low wages, and low work conditions and labour could even move from higher productivity to lower productivity, as Rodrik (2016) predicts, if low-income countries in Africa are missing out from higher productivity manufacturing due to technological/skills mismatch. This will result in higher
} 
Research has suggested that higher levels of educational achievement and cognitive skills are associated with overall economic growth (Hanushek \& Woessmann, 2012), as well as with the employment of a larger share of youth in modern wage jobs outside of agriculture (Lee \& Newhouse, 2012). Level of education has been positively correlated significantly on labour productivity, meaning that each increase in educational level can increase labour productivity (Shafii et al., 2018). However, if increases in educational attainment are not associated with a greater accumulation of skills, schooling will have a limited effect on overall growth and composition of employment - this is the current situation in sub-Saharan Africa. Rapid population growth and high child dependency ratios pressure governments to invest each year significantly more in education only to maintain the current enrolment rates and education standards. Improving quantity and quality of education means higher investments in education year after year in decades to come.

Lee et al. (2020) in their research paper confirm that for five sub-Saharan African countries the largest increases in labour productivity occur in countries where economies better match education and job opportunities (referred to as: higher returns to education). In countries with lower rates of return to education and slower fertility decline, the human capital increases are smaller and therefore take longer to offset the fall in income due to the falling levels of physical capital per worker. For example, Ghana, with the lowest rate of return to education of the countries analysed by Lee et al. (forthcoming), does not reach its initial labour productivity levels, even by the end of the century.

These results suggest that the turnaround in labour productivity set in motion by fertility decline may be enhanced by investments in education that build skills and match opportunities in the job market, which could result in even higher labour productivity (Lee et al., 2020). Given this relationship, high fertility countries that are unable to increase returns to education, may not see output per worker rebound over the remainder of this century unless fertility declines more rapidly (Lee et al., 2020).

- Savings:

Upgrading in education (in particular girls' education) can generally be realised in four ways: generating more national savings, generating higher tax revenues, curtailing investments in other sectors such as energy and health, or higher inward foreign capital flows. Most of the demography literature focuses on the implications of population growth on national savings. This could be explained because curtailing other investments important for growth is not desirable and inward foreign capital flows are not related to demography, while higher tax revenues are most likely the outcome of a structural transformation towards higher productivity.

For incomes to rise, investment needs to grow faster than the labour force, to ensure capital deepening. Capital deepening involves a growing demand for spending on education, health, roads, etc. These requirements have to be traded off against extra consumption. However, countries with the lowest absolute levels of investment per

inequality and create islands of modern activity without linkages to domestic economies, with a far less optimistic outlook for quality-job creation. 
potential new worker tend to be those also facing the fastest growth in their working-age populations (Bloom et al., 2017). They are stuck in a vicious circle as high child dependency ratio will reduce aggregate savings, reducing domestic investment, which will reduce productivity growth. Empirical research shows that high fertility rates are a burden for national saving, in particular household savings (Mason et al., 2016).

\section{- Open markets and trade:}

Although integration in the global economy is not as such linked with demography, indirectly it is linked with some of the above-mentioned determinants of productivity (e.g. technological change, investments). Being integrated within the global economy (but also regionally) could support African growth and productivity growth even in high population growth scenarios. However, this integration should be based on seeking domestic economic linkages, spillover effects on skills, and adaptation to technological change, to secure upgrading and productivity growth (Abdychev et al., 2018). Although the subSaharan African economy has been integrated with global markets since the 1990s most of the exports are still dominated by commodities, such as oil. Integration in global value chains is also progressing, although from relatively low starting points, and mainly related to agrobusiness and less to other labour-intensive sector such as textiles and tourism (Abdychev et al., 2018). Overall, sub-Saharan Africa remains the region that is the least integrated with the rest of the world and within itself (IMF, 2015; Arizala et al., 2018).

To conclude, when population growth is accompanied by low incomes, low levels of human and physical capital, limited political and social institutions, and less integrated in global economy, the literature is clear that these countries struggle because of a lack of structural transformation of the labour force, as the economy is not able to increase productivity enough. This has a major effect on income inequalities, particularly if many new young workers have little education. When a large proportion of workers are young and inexperienced, their productivity tends to be lower. Except for those who have more education than older workers, their starting wages will tend to be lower, and they must compete with each other. Relatively few will receive employer training to upgrade their skills. Over time, the weight of increasing numbers of the unskilled will hold down their wages in relation to those of skilled workers. However, increasing returns to scale in the production of physical or human capital may allow population growth to go hand in hand with rising income levels if these capital goods can be used to increase mechanisation and efficiency so as to overcome any diminishing returns in agriculture (due to lack of land expansion options) (Bloom et al., 2009).

Consequently, with continuing high population growth, African policymakers may need to focus on a combination of higher productivity growth in agriculture and rising opportunities in household non-farm activities (which means recognising informal enterprises as a viable livelihood option and instituting productivity enhancing strategies to harness employment gains from this sector) combined with targeted investments in labour intensive sectors outside agriculture as the most logical growth path for sub-Saharan African countries regarding their population dynamics (Fox \& Thomas, 2016; Quak \& Flynn, 2019).

\section{Gender implications}

For women, high fertility rates directly impact on their labour participation and outcomes, as it reduces their productive years of labour (Bloom et al., 2009). Bloom et al. (2009) find 
that each additional child reduces female labour force participation by between 5 and 10 percentage points for women between the ages of 20 and 44. Aggregating these estimates over the reproductive life of a representative woman, this implies that each birth reduces total labour supply by about 1.9 years per woman (Bloom et al., 2009). As such the literature is clear that women experience a labour market participation "penalty", as having a spouse and children is more likely to obstruct their labour market opportunities, while men experience a labour market participation "premium" associated with being married and having children (Wajnman, 2016). ${ }^{7}$

For sub-Saharan Africa most women combine care for children with informal and low productive work in agriculture or family enterprise. Large family sizes make it difficult for them to find more productive work outside these forms of labour. The literature suggests that labour opportunities in non-farm labour in more productive sectors, could have a major impact on decisions to reduce family size; however, due to the lack of structural transformation this is less likely to happen in Africa (Choudhry \& Elhorst, 2018; Stecklov \& Menashe-Oren, 2019). The concerns about the lack of "absorption" of new entrants into labour markets in the employment literature are mainly about "youth" - generally implying young men - and in particular their unemployment (Dancer \& Hossain, 2018). Importantly, there is also a strong focus on agriculture. For example, commercialisation of agriculture in development policies has a strong focus on individual economic empowerment, in which the idea is that women's individual empowerment through commercialisation could boosts productivity. However, these relationships are not as linear or as close as many expect (van den Bold et al., 2013).

\section{A key gap in the economic approach to women's empowerment until recently has been the neglect of women's responsibilities for unpaid care (Dancer \& Hossain, 2018). Feminisation of agriculture can only be turned into higher productivity if combined with less care taking roles (Stecklov \& Menashe-Oren, 2019). Women may be particularly affected if more integration into agricultural markets for basic goods comes with more volatility in the costs of goods needed for care (Scott-Villiers \& Kelbert, 2015). The evidence also shows that when women enter into global and other value chains in agricultural markets, the new structures of constraint include how those markets work to limit their bargaining power, exploit their effort, and ignore their responsibilities for the unpaid care sector, which relate to family sizes (Phillips, 2016).}

As such efforts by states to invest in rural women may do well to explore investments that accommodate some of the increased burden of care imposed on women and enable them to be more productive in the labour force, including family planning services in rural settings (Stecklov \& Menashe-Oren, 2019). In particular because there are likely to be important domains of intra-household negotiation over control of the benefits of commercialisation, this will affect the empowerment of women and girls in the context of high fertility and low education (Dancer \& Hossain, 2018). Furthermore, social norms need to be addressed where they hold back women and girls from job opportunities and labour market participation.

To make sure young women participate in the labour market, Wajnman (2016) demonstrate that future growth of the female labour force would come from the changing composition of the

\footnotetext{
${ }^{7}$ For Brazil Wajnman (2016) shows that among women with low levels of education, the labour force participation rate was below $50 \%$ in the prime working ages, whereas more than $80 \%$ of women with the highest levels of education were active in the labour force.
} 
population by level of education. However, girls' education is only a significant factor for a youth cohort if it is combined with a higher capital-labour ratio approach to stimulate economic development (Choudhry \& Elhorst, 2018). If not, they will be employed in the same family businesses and in agriculture, although in the longer-term better education can change behaviour as will be discussed later in Chapter 5 .

\section{How and when a fertility decline impacts on labour market}

- In theory a reduction in fertility, results in a smaller birth cohort which should increase output per capita and/or income per capita. However, the findings of different models show that a small reduction in the size of youth cohort does not translate into sizeable gains in youth employment perse.

- Economies with an increasing working-age population have an enormous economic opportunity, but without public or private investments these countries will struggle to increase output or improve productivity to increase income and job opportunities.

- An accelerated demographic transition could trigger productivity gains, higher participation rate of women in the labour force, increased incomes, and better-quality jobs. However, only when fertility induced increases in GNP per capita are (at least partially) reinvested in the human capital of future workers.

- If not, productivity gains of a lower child dependency ratio will fade away within one generation.

It is clear from the previous chapter that population dynamics are an endogenous factor to predict labour market outcomes; the current population growth in many sub-Saharan African countries directly and indirectly challenges labour market outcomes and economic prospects. However, it should not be assumed that fertility rates are fixed and remain high. In theory smaller birth cohorts, which decrease child dependency ratios, could increase output per capita if labour force participation rates among the working age population remain unchanged (Bloom et al., 2009). At the same time, if output per worker stays constant, then a decline in dependency ratio would lead to a rise in income per capita (Canning et al., 2015). ${ }^{8}$

It is important to understand the 'dependency effect' by estimating trends in dependency ratios and working age share of the population, because there is a "window of opportunity" that is available for a region or country to take economic advantage of declining fertility. That is the period where the working age population increases faster than the dependent age population. In the literature this is often referred to as reaping the benefit of the "demographic dividend". For example, Cummins (2019) estimates that this window of opportunity in Eastern and Southern Africa (ESA) has just started and could only last for 30 years. This is

\footnotetext{
${ }^{8}$ May and Turbat (2017) further suggest that the broad definition of the active (working-age) and dependent sub-populations do not really work for the African context, and could result in less accurate and economically less relevant dependency ratios. Routinely, working-age adults are defined as those being in the age bracket 15-64, whereas the dependents are those aged 014 as well as those being 65 and over. May and Turbat (2017) show that from an economic viewpoint, the dependency ratio should actually be defined as the number of dependents per person actively involved in the economy. Children remain dependents long beyond 15 years of age. That also was the conclusion of a study from the Centre de recherches en économie et finance appliquées de Thiès (CREFAT, 2016; cited from May \& Turbat, 2017) in six West African countries: Burkina Faso, Chad, Côte d'Ivoire, Mali, Mauritania, and Niger. Children were starting to generate a surplus (income minus consumption) at about age 28. The CREFAT also found that people started to generate a negative surplus at age 63 . As such May and Turbat (2017) suggest an economic dependency ratio with working age population aged 28-63.
} 
because the dependency ratio, which is currently at $78 \%$, is expected to bottom out around $54 \%$ in the 2060s before reversing course. Because the rate of change will begin to slow down significantly in the 2050s, ESA has to take advantage of the window of opportunity propelled by the rising share of working age persons in the population (Cummins, 2019).

However, the findings of different models show that a small reduction in the size of youth cohort does not translate into sizeable gains in youth employment per se. See in Box 5 some evidence from research.

Box 5: Evidence that shows that fertility decline has minimum youth employment effects.

- Lam and Leibbrandt (2014) measured that a decline from the growth rate of the youth cohort (15-24 year) of $4 \%$ per year to $0 \%$ per year in LMICs would reduce youth unemployment by $19 \%$, or about 3.5 percentage points at the mean unemployment rate of $18 \%$. This is a substantial decline, though still fairly modest relative to the large differences in youth unemployment across time and countries. The results for women are quite similar to the results for men. Regarding Africa, to quote Lam and Leibbrandt (2014: 14): "The countries with the fastest growth rates are estimated to have quite low youth unemployment, however, a characteristic of poor agrarian economies. Changes in youth demography may therefore play only a modest role in influencing the dynamics of youth unemployment in Africa in coming decades."

- Newhouse and Wolff (2014), who did a cross-country panel study of 83 low- and middle-income countries, finds that there is a moderate but significantly positive labour market outcome for young adults aged 15-24 who were born in smaller cohorts; but only for middle-income countries. In lowincome countries, young adults that are born into smaller cohorts are less likely to work, but school attendance remains unchanged. The evidence shows that in middle-income countries this group is more likely to have a wage job (overall a $10 \%$ decline in cohort size is associated with a 1.6 percentage point increase in wage employment, mainly for men when they are among 25-29 and 40-44 year and working women aged 15-19 who are more likely to work as wage employees), less likely to be unemployed (but only a reduction of $0.7 \%$ ), and more likely to work outside of agriculture (a reduction of cohort size of $10 \%$ is associated with a 6 percentage point decline in the share of youth engaging in agriculture, for both men and women aged between 1519). These improvements in labour outcomes in middle-income countries only persist in the first years after entering the labour market, resulting in slightly higher wages, but do not persist into adulthood.

- Canning et al. (2015) measured that a $10 \%$ decline in cohort size is associated with a 2.5 percentage point reduction in the share of working youth. Typically, the moderate reduction in the share of working youth for smaller cohorts does not appear to translate into higher rates of school attendance. Smaller cohorts seem to be associated with a small shift from industry to service jobs, but it is difficult to know whether or by how much the shift benefits workers. Finally, the link between cohort size and employment outcomes are weaker for individuals 25 to 34 years old, who have already finished school, than it is for youth aged between 15-24. Smaller cohorts are associated with a smaller share of unpaid workers in middle age, but the result is not statistically significant. Therefore, Canning et al. (2015: 140) conclude: "there is little evidence that African youth in smaller cohorts are more likely to work or, if they work, are more likely to work in either salaried or non-agricultural jobs, which tend to be more productive".

These findings show that economies with an increasing number of persons of working age have an enormous economic opportunity, but without public or private investments these countries will struggle to increase output or improve productivity to increase income and 
opportunities to improve well-being (Turbat, 2017). There is a growing amount of evidence that only with the right interventions (e.g. by promoting and upgrading voluntary family planning services, girls' education, women empowerment, skills training of the working age population to adapt to technological changes) an accelerated demographic transition could trigger productivity gains, higher participation rate of women in the labour force, increased incomes, and better-quality jobs (Choudhry et al., 2016). Furthermore, falling fertility now and under such circumstances will only have any impacts on labour markets and their outcomes in over 15 years.

Simulations by Ashraf et al. (2013) and Mason et al. (2016) show that a full demographic dividend in Africa will only materialise, if a substantial increase in human capital investments reinforces the fertility decline (Bloom et al., 2017). Ashraf et al. (2013) and Mason et al. (2016) both find that a decline in fertility rates will initially result in a rising share of the working-age population as the initiator of shifting labour market outcomes, but only if combined with investments in physical and human capital. Mason et al. (2016) show that the increase in human capital rather than physical capital drives the demographic dividend once it becomes quantitatively important.

The remaining question is, are such investment feasible for sub-Saharan African countries? Fortunately, many studies show that human capital investments could be feasible when fertility rates drop. However, there is a caveat. This is only possible if fertility induced increases in GNP per capita (through the mechanical effect of increasing the ratio of the working to non-working population) are (at least partially) reinvested in the human capital of future workers (Lee \& Mason 2010). If investments in human capital are made while fertility declines, GNP per capita eventually stabilises at around $40 \%$ above its prefertility transition level (Lee \& Mason, 2010). For example, Eloundou-Enyegue and Hirschl (2017) show for sub-Saharan African countries with the highest fertility rate declines, that on average, declines in national fertility were followed by reduced dependency ratios and, ultimately resulted in substantial boosts to public spending in education per pupil. They conclude that while a few countries also achieved schooling progress over this period without a decline in fertility, "they might have seen even bigger gains had dependency ratios declined during that period".

In contrast, if investments in human capital (e.g. health and education) do not take place the productivity gains of a lower child dependency ratio will fade away within one generation. In such settings, the relatively low-productivity population ages without having the opportunity to increase savings for retirements, increasing the burden towards high old dependency ratios. As such, although African leaders have showed interest in a demographic dividend and see the opportunities of falling fertility rates, they remain sceptical about a prospect of a rapid ageing population. 


\section{Understanding behavioural implications}

- Demographic change may also lead to important behavioural change, resulting in feedback loops affecting both demography and labour markets. For example, higher female wages and women labour market participation is largely the result of behavioural changes due to reductions in fertility often combined with the child-quality effect of better girl's education for future generation.

- There is some evidence of a "gender-equity dividend", which is the result of work-family conflicts within the context of an improved institutional environment for gender equality and women participation in labour force. In such circumstances, highly educated women are more likely to decide not to marry or have children in order to prioritise their independent careers. If they are followed by other groups of women this could improve the negotiation positions for women in households, changing social norms.

- In theory savings rates tend to increase relatively steeply as the demographic transition advances, which could improve the relative competitiveness of these countries, which could result in more and better jobs and a broader economic development. However, in the sub-Saharan African context this does not seem to happen. This suggests that income levels are too low in most countries to generate such change due to higher consumption needs instead of savings within smaller households.

- The literature suggests there is more an indirect link between fertility and household savings rates in sub-Saharan Africa as development proceeds, which over time should increase productivity growth (e.g. as more women work in the modern sector or urbanisation increases or inclusive financial markets improve, monetised savings rise and fertility falls).

- Higher life expectancy can also change behaviour through saving and consumption decisions. However, in sub-Saharan Africa this effect is less profound due to high underemployment levels. Therefore, the literature suggests the importance of policies that influence employment and labour productivity over the lifecycle to increase better jobs and improved labour income.

In addition to age structure effects combined with investments in human capital, demographic change may also lead to important behavioural change, resulting in feedback loops affecting both demography and labour markets. ${ }^{9}$ This section looks into some of the most important behavioural changes, as were mentioned in the literature, which relate to gender-equality, and the relation to health and life expectancy on savings and consumption, which all affect labour market outcomes.

\section{Gender-equality factor}

Fertility reductions can free up time from childcare and can increase female labour participation, as well as investments in each child's health and education. Kleven and Landais (2017) conclude after analysing a database that compiles 248 surveys from 53 countries between 1967 and 2014, covering a wide range of per capita income levels, that the single most important factor behind improved gender equality in labour market outcomes (earnings, labour market supply, wage rates) is reduced fertility during the demographic transition followed by the gender convergence in educational attainment. Changes in the values or norms surrounding the role of women with children serve as a reinforcing mechanism for gender convergence (Kleven \& Landais, 2017).

\footnotetext{
${ }^{9}$ The Population Reference Bureau also mentions the importance of political stability as a factor. This review will not look into conflict as an aspect of behaviour change, which could affect labour market outcomes. To understand the link between demography and conflict better, see K4D report https://opendocs.ids.ac.uk/opendocs/handle/20.500.12413/15755
} 
During the demographic transition, total fertility rates often fall by roughly four births per woman. Bloom et al. (2009) measured that this fertility reduction increases total female labour supply by around $18 \%$ (or an additional 8 years out of a potential lifetime supply of around 45 years), which implies gains in income per capita of around $7 \%$. If the transition from high fertility to low fertility is permanent and can be established in a relatively short-term period, there are long-run effects on female labour participation, and the gains in income per capita will be permanent. Bloom et al. (2009) also find by using a panel of 97 countries over the period 19602000 that removing legal restrictions on abortion significantly reduces fertility. They estimate that, on average, a birth reduces a woman's labour participation by almost 2 years during her reproductive life. This implies that behavioural change, in the form of increased female labour supply, contributes significantly to economic growth during the demographic transition when fertility declines.

Bringing gender equity into the realm of the age profile of labour outcomes could help economies to adapt to population dynamics (Donehower, 2016). Anderson and Kohler (2015) argue that gender equality regimes are dynamic and closely tied to changes in fertility through a demographic feedback mechanism, which they refer to as a "gender-equity dividend". This dividend is the result of work-family conflicts within the context of an improved institutional environment for gender equality and women participation in labour force. First, the group of highly educated women could decide in such circumstances not to marry or have children in order to prioritise their independent careers, which would be followed by other groups of women (Bianchi et al. 2000; cited from Anderson \& Kohler, 2015). In high-income countries there is evidence that these conflicts in the first part of the 20th century resulted in significantly lower fertility rates and a scarcity of women in the marriage market, which in turn facilitated changes in gender norms and the spread of greater gender equity due to greater male-female bargaining within the household. Greater gender equity is then likely to stabilise fertility rates at a low level (Anderson \& Kohler, 2015).

It is not clear if the same could happen in the low- and middle-income countries, but there are signs that some sort of "gender dividend" could occur in emerging economies such as India and Brazil. In Brazil, fertility rates are already below replacement for nearly a decade. Wajnman (2016) mentions that in Brazil women with a spouse or partner were $66 \%$ less likely to be active in the labour force than their single peers, while men with a spouse or partner were $85 \%$ more likely to be active in the labour force than their single peers. ${ }^{10}$ Much more studies are needed to understand exactly what underpins these dynamics. Anderson and Kohler (2015) themselves argue that it is not only the changing gender dynamics and male-female bargaining in households and in the job market resulting in low(er) fertility in some emerging economies, but for example also high costs of education and living costs (e.g. in Brazil). For sub-Saharan African countries such trends are not expected to happen in the next decade, but in some countries

\footnotetext{
${ }^{10}$ Wajnman (2016) mentions that there are two stages: The first stage was characterised by an influx of women to the labour market, which destabilised traditional breadwinner/homemaker family arrangements, as well as increased rates of divorce and cohabitation and reduced levels of fertility. The second stage was characterised by the development of more equal partnerships of women and men in which men took on greater responsibility for domestic work. However, Wajnman (2016) stressed that countries such as Brazil are still in the first stage, where the unequal division of labour in the household was still constraining women's participation in the labour market and working conditions were still worse for women than for men. Policy measures, such as shared parental leave, public childcare, pre-school and elder care, as well as flexible working hours are needed to facilitate career and family balance (Wajnman, 2016; Pignatti, 2016).
} 
(e.g. South Africa) or in some highly urbanised regions with an increasing urban middle class these dynamics could occur.

This also could relate to the observation of Mammen and Paxson (2000, cited in Bloom et al., 2009) that the relationship between female labour force participation rates and per capita income around the world is U-shaped. Low-income countries are mainly agricultural economies, where most households live in rural areas and female participation is high. This female participation relates to family-enterprise responsibilities and agricultural work mainly in the informal economy. In this situation, high fertility goes hand in hand with high female labour participation. Data from Senegal in 2011 indicated that men spent no more than a few hours per week on housework on average. Women's time spent in paid work was about half that of men, but they engaged in substantially more household production work than men across all ages (Donehower, 2016).

Research on total time use had proven that there were negative effects to specialising in household production, such as less access to money, as well as constraints on participation in paid work, education, or leisure activities (Donehower, 2016). Lower levels of fertility in the future would free up resources and time (Donehower, 2016).

In contrast, women labour market participation seems to be lowest in urbanised, middleincome countries as the separation of home and work environments in urban areas can make it difficult to combine raising a family with working, contributing to lower participation rates (Mammen \& Paxson, 2000: cited in Bloom et al., 2009). In these circumstances some women might prefer work above family, which could offset the "gender dividend". Female participation rates are again high in high-income countries. In these countries the opportunity cost of exiting the workforce for childcare is high; female labour force participation rates are high and fertility rates are low in this environment. As such from the literature it is clear that the effect of higher female wages on female labour participation works to a large extent through reductions in fertility. Research also shows that while an array of policy interventions are available to governments to address gender gaps in the labour force, it is critical that governments prioritise efforts to reduce the double burden of work that employed women face in balancing jobs and gendered expectations around household responsibilities, including care for children (Pignatti, 2016).

\section{Savings factor}

An accelerated demographic transition increases the number of workers naturally, and with the right human capital investments it could on the macro level increase output, which creates more income, which facilitates greater savings and investment. There is also a more direct and micro level relation between lower fertility rates and higher savings as smaller family sizes require fewer resources to maintain if consumption per child stays the same.

Cummins (2019) shows that in low-income countries, where the demographic transition is still at a relatively early stage, savings rates are very low $-15 \%$ of GDP on average. In contrast, uppermiddle income countries, which are generally nearing the end of the demographic transition, have a much higher savings rate of $33 \%$ of GDP on average. That savings rates tend to increase relatively steeply as the demographic transition advances is important to encourage productive investment, which could improve the relative competitiveness of these countries, which could result in more and better jobs and a broader economic development (Cummins, 2019). 
However, it is not as straightforward to conclude in the sub-Saharan African context that at any given level of output per worker, lower numbers of dependents cause consumption to fall, resulting in rising savings per capita. The evidence in the literature is clear for sub-Saharan Africa that an increase in the share of workers (proxied by a drop in the child dependency ratio) does not lead to higher saving (Canning et al., 2015). The bulk of monetised household savings in Africa is produced by relatively few wealthy families, whose savings are little affected by the burden of their dependents. The majority of the households are poor and tend to have higher fertility, giving them no choice but to pay for what their children consume by reducing their own consumption resulting in no or very low monetarised savings (as they have no access to bank accounts). In that situation even with fewer children, these households might not increase their savings, but instead might consume a bit more themselves. Higher consumption would also be good for the local economy and could improve labour market outcomes in rural and urban areas. The main behaviour effect related to savings in Africa could be due to higher consumption needs instead of savings within smaller households, or to the perception that children are a substitute for savings to provide old-age care, which means to retain high fertility rates.

The literature remains cautious on drawing conclusions, because African data on household income are rarely reliable, rendering it impossible to compute accurate saving rates.

Furthermore, as Canning et al. (2015) explains, a majority of households, particularly in rural areas, might rely on precautionary saving to manage risks rather than life cycle saving. Even in the case of precautionary saving, other informal mechanisms for managing risks, such as support of the community or family or the purchase of land or animals, are not captured by the data on savings.

\section{Life expectancy factor on savings and consumption}

Lower mortality and longer life spans may affect retirement and savings decisions as well (Bloom et al. 2017). However, again Africa presents less evidence of a life-cycle pattern of saving: in other words, increases in life expectancy do not seem to have a significant effect on aggregate savings (Canning et al., 2015). As such, the African case weakens the theory of life-cycle saving as it seems that "Africa may simply be too poor for such saving to play a large role in capital accumulation" (Canning et al., 2015: 149). Even by looking only at urban wage earning households, Canning et al. (2015) measure that only in Kenya (from the five countries studied) show some evidence of life-cycle saving, with rising age of the head of household initially correlated with saving, but then declining. However, as incomes could rise in Africa over the next years, the importance of age structure is likely to increase. As such, the literature suggests there is more an indirect link between fertility and household savings rates in Africa as development proceeds, which relates to productivity growth (e.g. as more women work in the modern sector or urbanisation increases or inclusive financial markets improve, monetised savings rise and fertility falls).

Lai (2016) notes that between 1995-2000 and 2010-2015 life expectancy at birth in Africa increased by 7.3 years, the largest increase among the six major regions of the world. Half of the total increase in the African life expectancy was due to improvements in survival before age five, while increased survival above age 60 years contributed only about 0.6 years, or $9 \%$, to 
the total gain in life expectancy in the region. ${ }^{11}$ Overall, the number of lifetime effective years worked is five years more, on average, in rich countries than in poor countries, but only because survival rates at working ages are higher in rich countries (Mason \& Lee, 2013). ${ }^{12}$

In their life cycle model, including data from 34 countries worldwide, including in Africa, Mason and Lee (2013) show that effective years of consumption increases sharply with life expectancy, by 1.34 years for every additional year of life expectancy. However, turning to effective labour they find a much weaker relationship; an increase in life expectancy by one year leads to an increase in effective years of work of only 0.13 years. This means that life expectancy increases mostly result in behavioural changes in consumption and less in labour supply. The African countries appear to be outliers with much lower effective lifetime labour than expected based solely on their life expectancy at birth. Mason and Lee (2013) attribute this to the high unemployment and/or underemployment of young workers in Africa, partly due to high population growth.

As such this study shows that in upper-middle income and high-income countries, the age patterns of work and consumption both play an important role in determining the lifecycle dynamics of a country. But in low-income countries, and particularly in Africa, only age patterns of work appear to be important. Therefore, labour markets and policies that influence employment and labour productivity over the lifecycle are key to determining the level of labour income in the sub-Saharan African context.

Canning et al. (2015: 155) conclude:

"[I]n African countries, both the level of income and the number of dependents affect household behaviour. However, there is no evidence of a relationship between age and saving rates. It may be that the lifecycle model only begins to play a role in determining saving behaviour at higher levels of income than are currently seen in Africa."

\footnotetext{
${ }^{11}$ Nutrition is important for the development of children into adulthood, also affecting labour force productivity. A fast-growing labour force that is well-educated and fully physically and cognitively developed is much better positioned to contribute to increased economic output and take advantage of broader opportunities presented by the demographic transition (Lutz et al. 2019). A youth cohort that is completely free of any impacts of stunting is important and smaller family size could improve the nutrition per child. However, a behavioural change is needed in diet intake as increasing resources per child do not automatically mean better nutritional intake.

${ }^{12}$ Lower income countries 31.5 years of effective labour is supplied over the lifetime which is precisely half of life expectancy. Lifetime labour increases to 35 years in upper-middle income countries and 36.1 years in high income countries. However, in the high-income countries, lifetime labour is only 45 percent of life expectancy (Mason \& Lee, 2013).
} 


\section{Using macro-simulation models}

- Most studies that measure the labour market impacts of population dynamics use cross-country regression models, however these aggregate models do not identify well the factors that influence fertility rates, and they often lack the ability to model country-specific factors in detail.

- Macro-simulation models of economic growth have been developed to measure outcomes for different fertility scenarios, considering the effects on capital deepening, the propensity of parents to substitute child quality for quantity, and labour force participation.

- Although macro-simulation models are sophisticated, Mason et al. (2016) argue that many assumed mechanisms associated with demography and labour market outcomes are still not fully understood.

As we have seen, the literature suggests that demographic change (fertility, age structure) in itself is only the initial trigger of a process that potentially changes labour market outcomes, but must be reinforced by social and economic factors, including human capital, and need to take into account behavioural implications and feedback loops, to fully benefit of the window of opportunity. Most studies that measure the impacts use cross-country regression models (Bloom et al., 2017), however these aggregate models do not identify well the factors that influence fertility rates, and they often lack the ability to model country-specific factors in detail (Karra et al., 2017). Recently, macro-simulation models of economic growth have been developed that could measure outcomes for different scenarios (e.g. level of fertility decline and level of human capital investment). These models calculate per capita output trajectories for various demographic scenarios, considering the effects on capital deepening, the propensity of parents to substitute child quality for quantity, and labour force participation.

Box 6 shows three macro-simulation models have been developed and used widely in research and policy and give comprehensive evidence of how age structure change and fertility declines affect labour market outcomes and economic growth and vice versa.

\section{Box 6: Macro simulation models}

- Karra et al. (2017) model is based on the work of Ashraf et al. (2013). Ashraf et al. (2013) examine the economic effects of fertility decline through changes in age structure, female labour force participation, investment in children's education, and increases in the capital-labour ratio. Karra et al. (2017) add a channel that links fertility decline to improved health outcomes for children. The assumption is that smaller family sizes and longer intervals between birth could increase physical and cognitive development as a result of additional health investments in children. Karra et al. (2017) also add a mechanism through which the change in the population age structure due to fertility decline may increase savings rates. Higher savings rates from reductions in fertility rates may, in turn, boost the capital-labour ratio over and above the effect of having smaller inflows of working-age people boosting higher productivity (Karra et al., 2017). Finally, they add the effect of an increase in contraceptive use through an expansion of family planning programmes and the possibility of subsequent further fertility reductions as fertility reacts endogenously to induced changes in social and economic conditions (e.g. feedback mechanism in girls education). The model is tested to look at how these different channels impact on changes in modern- and traditional-sector wages and labour supplies to allow insights on how a structural transformation might be triggered through age structure changes and fertility declines.

- National Transfer Accounts model which is used within the United Nations and based on leading research work by Andrew Mason and Ronald Lee, is a model that features generational economic life cycle changes that could occur due to shifts in age structures. The economic life 
cycle account provides a measure of the extent to which individuals at each age are able to provide for their material needs through their current labour (UN, 2014). The economic life cycle account is composed of consumption, labour income and the difference between the two-the life cycle deficit/surplus. The economic life cycle cannot exist without economic mechanisms and social institutions that facilitate the reallocation of resources across age. The model shows two economic mechanisms that lead to reallocations: first, transfer systems embodied in families, nonprofit institutions and governments channel resources across age; and second, assets that provide a store of value that allows economic resources to be shifted over time and across age (UN, 2014).

- DemDiv model was created by the Health Policy Project with support from USAID and is a multiple scenario model showing how different interventions and investments in family planning, education, and the economy can generate a demographic dividend of higher productivity and economic growth. Conceptually, the model's structure is also based on Ashraf et al. (2013). The difference in the Demdiv model is the specific target group of policymakers outside the health sector in mainly sub-Saharan Africa (Moreland et al., 2014). It is a two-part model describing demographic and economic changes with equations to estimate employment, investment, and GDP (Moreland \& Madsen, 2017). The demographic component underlies the model structure, projecting child mortality, dependency ratio, fertility, population size and structure, and life expectancy (Moreland et al., 2014). These demographic calculations then feed into the economic model, which consists of three equations describing capital formation, employment growth, and total factor productivity as a function of age structure and other social and economic variables (Moreland et al., 2014). Users can choose to design multiple scenarios to see the effects of different policies by manipulating the variables on education, family planning, and economy (Moreland \& Madsen, 2017).

The research findings of these models used in the sub-Saharan African context are in line with what has already been argued in previous chapters. What all models show is that when the country prioritises economic, social, and demographic factors to achieve the socioeconomic transformation productivity growth, higher incomes and per capita GDP would increase significantly.

Karra et al. (2017) in their simulation model show for Nigeria that in the endogenous low fertility variant scenario fertility could fall by an additional 0.55 births after 50 years and by 0.35 births by the end of the 90 -year in which period per capita income increases by $97.4 \%$. They conclude that when fertility is low, in the short to medium-term, the main reason for higher income effects is the larger share of the workforce that moves into the modern sector of the economy. However, the model also shows that modern-sector capital per worker is fairly stable and approximately equal in the two fertility scenarios until around 2040, after which modernsector capital per worker under the endogenous low-fertility scenario is projected to grow at a faster rate. That the capital per worker is not expected to increase substantially in either scenario for around $\mathbf{5 0}$ years is because of continued low savings rates. "Only when income levels rise substantially do domestic savings accelerate. This assumption highlights the potential role of foreign investment over the medium run in sub-Saharan Africa as a source of funds for investment, given the weak initial rates of domestic savings" (Karra et al., 2017: 252)

Karra et al. (2017) also conclude that in the long run, lower fertility leads to increases in female education, which in turn lowers fertility in the next generation and produces a multiplier effect from any initial change in fertility. This is also the conclusion of Lee et al. (forthcoming), who use the Karra et al. (2017) model, and find that, although not expected to 
increase soon in the next two decades, the biggest overall contributor to productivity and economic growth is the feedback loop between fertility decline and education. As the total fertility of each cohort of parents declines, increased investment in the "quality" (health and education) of their children becomes possible, resulting in smaller, healthier, and better-educated cohorts slowly moving into working age. As such Lee et al. (2020) expect that countries with faster fertility decline will see the earliest and largest increases in labour productivity, particularly where the interaction of fertility and education is maximised through greater returns to education.

This is in line with Mason et al. (2016) using the National Transfer Account model also for Nigeria, which shows that fertility decline accompanied by an increase in human capital spending provides a substantial boost to economic growth. Given the low or medium fertility scenario per capita, consumption will grow more rapidly by 0.4 to 0.6 percentage points between 2010 and 2040 due to the growth in the relative size of the workforce. However, the biggest gains come later, as per capita consumption growth is higher by about 1.5 percentage points between 2040 and 2100. The large gains are a consequence of economic growth due to greater investment in physical and human capital. Radical fertility decline would produce gains that come earlier and would be substantially greater (Mason et al., 2016).

Although these models are sophisticated, Mason et al. (2016: 24) argue that many assumed mechanisms are still not fully understood: "[T]he connections between investment and outcome measures such as educational attainment or cognitive development are not understood. Moreover, our measure of cost could be improved by including the opportunity cost of students and the value of non-market inputs to human capital, such as the time of parents and grandparents". They go further to assume that they do not think that the decline in fertility is necessarily the cause of greater human capital investment. "Fertility decline and rising human capital investment are mutually reinforcing, but both are influenced by a host of forces including policy." 


\section{Annex 1: Population dynamics in sub-Saharan Africa}

- The African region (together with South Asia) has the highest concentration of young people and this will remain the case for many years to come. Almost $60 \%$ of Africa's population is under the age of 25 (Population Council, 2020). As such, the age structure of most of Africa's countries is shaped in a pyramid, with a broad base of youth (see Figure A1).

- Sub-Saharan Africa could account for more than half of the growth of the world's population between 2019 and 2050 (Lam et al., 2019). The Northern Africa region is also projected to continue growing through the end of the century, although at a slower rate than sub-Saharan Africa (UN DESA, 2019).

- Several of Africa's most populous countries will drive much of the anticipated population change between 2019 and 2050, including Nigeria, Democratic Republic of the Congo (DRC), Ethiopia, Tanzania, and Egypt.

- Research shows further that for sub-Saharan Africa "fertility inequality"13 is relatively high compared with other continents. This can be primarily explained by the early stage in the fertility transition of most countries in the region, which is characterised by higher fertility inequality (Eloundou-Enyegue et al., 2017).

- Some countries show a more advanced decline in fertility rates, mostly in Eastern Africa (e.g. Kenya, Rwanda, Ethiopia and Malawi), while others, mainly in the Sahel region and central regions of Africa (e.g. Niger and DRC) have started the transition later and often at a slower pace. ${ }^{14}$ Gerland et al. (2017) show that in Southern Africa fertility rates declined already since the 1950s and it has become the region with by far the lowest TFR.

- Both Western and Eastern African regions started the process of declining TFR at approximately the same time, at the start of the 1980s. However, the pace of decline is much faster in Eastern Africa than in Western Africa. The Central African region was the latest to start the transition in the 1990s and although the pace of decline is higher than in Western Africa, Central Africa has still the highest TFR for the region (Gerland et al.,2017).

- Research shows that in the sub-Saharan African context the current fertility decline happens with lower income levels as would be expected compared to other regions in the world (Bongaarts, 2017). As such, the literature notes that the relationship between higher incomes (economic growth) and the demographic transition is far more complex and unfolds differently per country (Schultz, 2015). ${ }^{15}$

- The demographic transition literature is conclusive that the drivers for the transition are women empowerment, female education, voluntary family planning, reduced child mortality,

\footnotetext{
${ }^{13}$ Finlay (2018) shows that for sub-Saharan Africa those in the richest wealth quintiles have had a more rapid decline in fertility rates than those in the poorest wealth quintiles. "The rapid decline for those in the richest wealth quintiles is attributable to delayed marriage and modest increases in contraceptive use. Although the poorest lag in fertility decline, postpartum abstinence and breastfeeding are the most important factors for them for fertility regulation" (Finlay, 2018: 1).

${ }^{14}$ See Quak, E. \& Tull, K. (2020). Evidence of successful interventions and policies to achieve a demographic transition in subSaharan Africa: Ethiopia, Rwanda, and Malawi. K4D Emerging Issues Report No.30, Brighton, UK: Institute of Development Studies. https://opendocs.ids.ac.uk/opendocs/handle/20.500.12413/15426

${ }^{15}$ Although contested, particularly in the African context, it has been claimed that better economic prospects could result in higher incomes for households, which could generate higher tax revenues to invest in public services (e.g. health and education) to trigger fertility decline.
} 
and sexual and reproductive health and rights (SRHR) (Cleland \& Potter, 2019; Quak \& Tull, 2020).

- There is now wide speculation of a so called "demographic dividend" which states that a sharp fall in the "dependency ratio" 16 as a result of an accelerated demographic transition could impact economic growth, but only for countries that manage to decrease fertility rates significantly over time (Groth \& May, 2017; Karra et al., 2017; Bloom et al., 2017).

Figure A1. Population pyramid versus bulb ${ }^{17}$

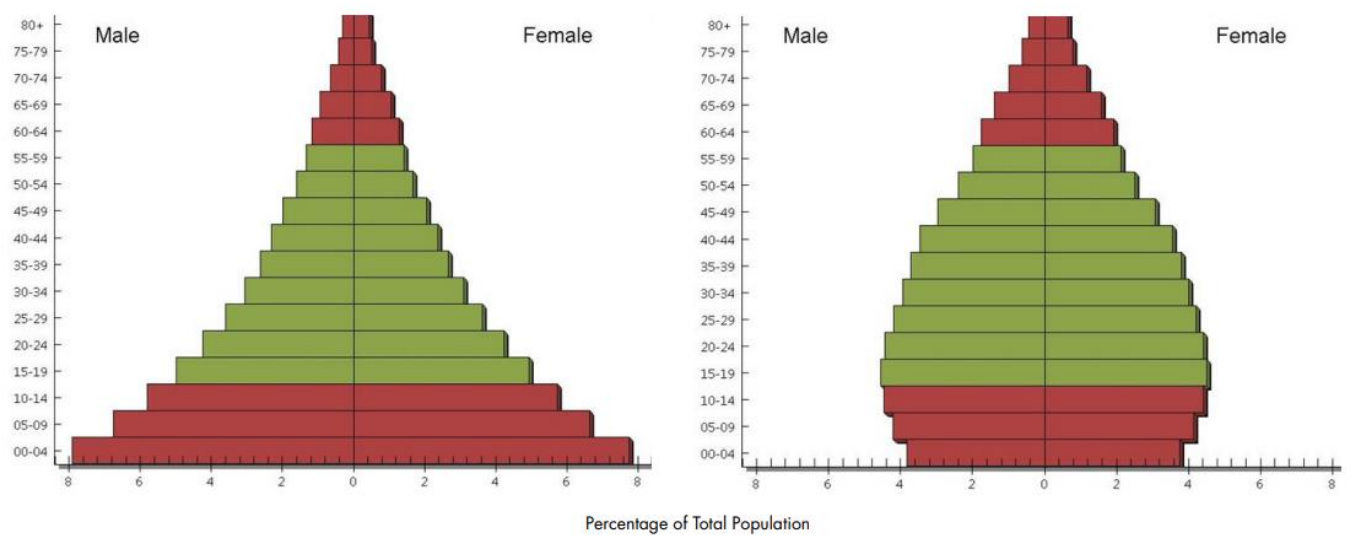

Source: Kenya National Council for Population and Development \& Health Policy Project (2014, p. 2). Reproduced with permission.

\footnotetext{
${ }^{16}$ In Figure 1 the working-age sub-population has a different colour from the non-working sub-population. In the pyramid, with high fertility rates and continued lower mortality rates, there is a high child dependency ratio, as a relatively small share of working-age sub-population need to take care of a high share of young dependents. In the bulb shape this has changed, and a lower dependency ratio has occurred as the working-age sub-population share increased.

${ }^{17}$ Most of Africa's countries show the pyramid shaped age structure of their population due to high and slow declining fertility rates in combination with continued infant and child mortality declines. With an accelerated demographic transition with continued fertility rate declines over time, the population structure could change into a bulb shape. Some countries in Africa are at the very start of the process of reshaping the pyramid into a bulb (e.g. Botswana, Kenya, Morocco), while some other countries started this earlier but have stalled (e.g. Egypt, South-Africa). Source: Index Mundi website using data from CIA World Factbook.
} 
Figure A2: Population by SDG region: estimates, 1950-2020, and medium-variant projection with 95\% prediction intervals, $2020-2100$

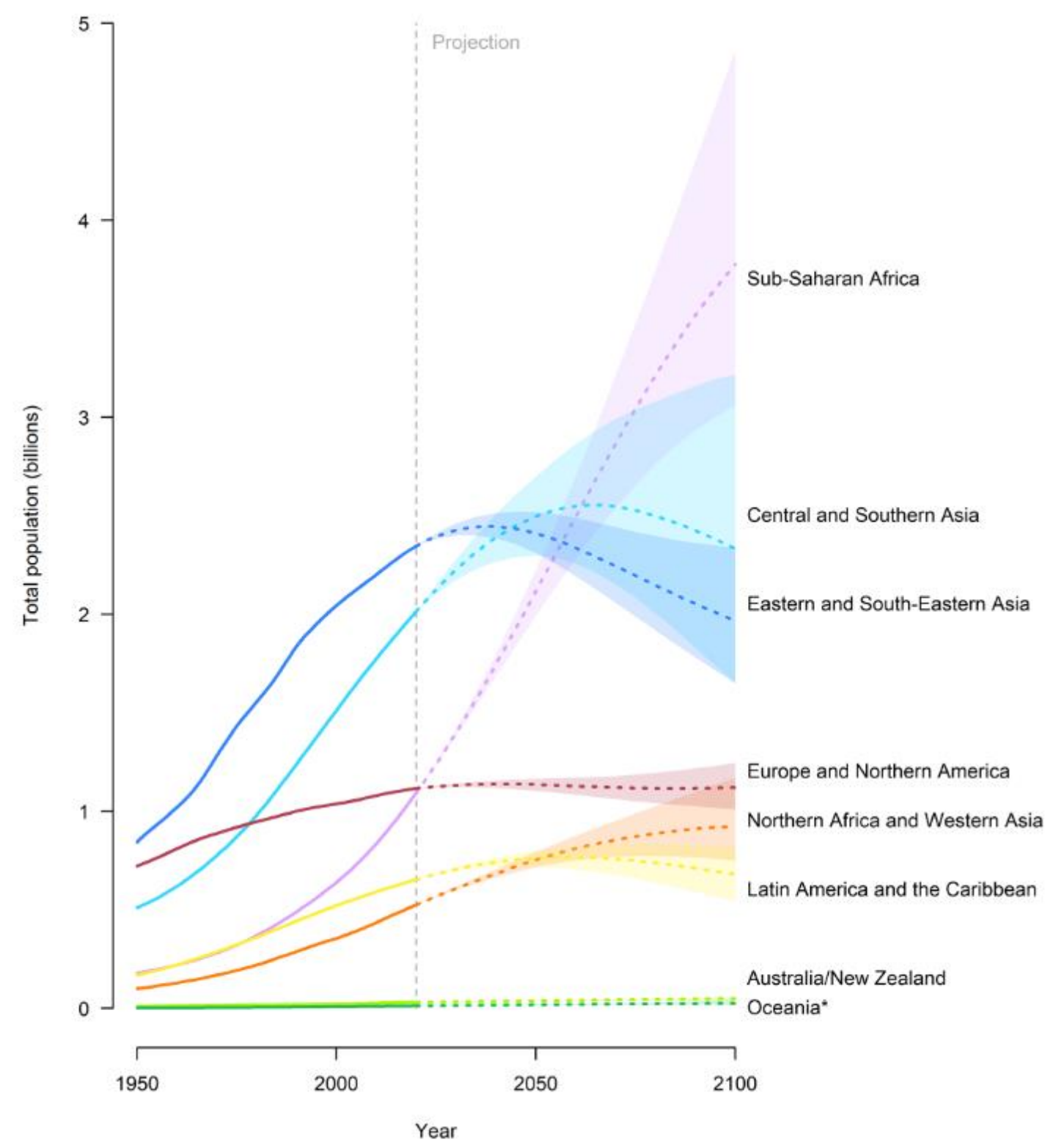

Source: UNDESA, Population Division (2019, p. 7). Available under CC BY 3.0 IGO. *excludes Australia and New Zealand 


\section{References}

Abdychev, A., Alonso, C., Alper, M. E., Desruelle, M. D., Kothari, S., Liu, Y., Perinet, M., Rehman, S., \& Schimmelpfennig, M. A. (2018). The Future of Work in Sub-Saharan Africa. International Monetary Fund. https://www.imf.org/en/Publications/Departmental-PapersPolicy-Papers/Issues/2018/12/14/The-Future-of-Work-in-Sub-Saharan-Africa-46333

African Development Bank. (2016). Africa's Youth in the Labour Market (African Development Report 2015. Growth, Poverty and Inequality Nexus: Overcoming Barriers to Sustainable Development). African Development Bank. https://www.afdb.org/fileadmin/uploads/afdb/ Documents/Publications/ADR15_UK.pdf

Allen, T., Heinrigs, P., \& Heo, I. (2018). Agriculture, food and jobs in West Africa (West African Papers No. 14). Paris: OECD. https://doi.org/10.1787/dc152bc0-en

Anderson, T., \& Kohler, H.-P. (2015). Low Fertility, Socioeconomic Development, and Gender Equity. Population and Development Review, 41(3), 381-407. https://doi.org/10.1111/j.1728-4457.2015.00065.x

Arizala, F., Bellon, M., MacDonald, M., Mlachila, M., \& Yenice, M. (2018). Regional Spillovers in Sub-Saharan Africa: Exploring Different Channels. International Monetary Fund (IMF). https://www.imf.org/en/Publications/Spillover-Notes/lssues/2018/08/01/RegionalSpillovers-in-Sub-Saharan-Africa-Exploring-Different-Channels-46063

Ashraf, Q. H., Weil, D. N., \& Wilde, J. (2013). The Effect of Fertility Reduction on Economic Growth. Population and Development Review, 39(1), 97-130. https://doi.org/10.1111/j.1728-4457.2013.00575.x

Baah-Boateng, W. (2016). The youth unemployment challenge in Africa: What are the drivers? The Economic and Labour Relations Review, 27(4), 413-431. https://journals.sagepub.com/doi/10.1177/1035304616645030

Basnett, Y., \& Sen, R. (2013). What do empirical studies say about economic growth and job creation in developing countries? (p. 41). Overseas Development Institute (ODI). https://assets.publishing.service.gov.uk/media/57a08a2340f0b652dd0005a6/Growth_and_I abour_absorption.pdf

Beegle, K., \& Christiaensen, L. (2019). Accelerating Poverty Reduction in Africa. World Bank Group. https://openknowledge.worldbank.org/handle/10986/32354

Bennell, P. (2007). Knowledge and Skills for Development. https://www.semanticscholar.org/paper/Knowledge-and-Skills-for-DevelopmentBennell/28423e9e1ef81c9f3cc3076b8ab2f6c6f3454061?p2df

Bloom, D. E., Canning, D., Fink, G., \& Finlay, J. E. (2009). Fertility, female labor force participation, and the demographic dividend. Journal of Economic Growth, 14(2), 79-101. https://doi.org/10.1007/s10887-009-9039-9 
Bloom, D. E., Kuhn, M., \& Prettner, K. (2017). Africa's Prospects for Enjoying a Demographic Dividend. Journal of Demographic Economics, 83(1), 63-76.

https://doi.org/10.1017/dem.2016.19

Bongaarts, J. (2017). The effect of contraception on fertility: Is sub-Saharan Africa different? Demographic Research, 37(6), 129-146. https://doi.org/10.4054/DemRes.2017.37.6

Bongaarts, J., Gragnolati, M., Ahmed, S. A., \& Corker, J. (2020). Population, development, and policy (p. 39). Population Council.

https://knowledgecommons.popcouncil.org/cgi/viewcontent.cgi?article=2183\&context=dep artments_sbsr-pgy

Brooks, K. (2018). Rising absolutely, declining relatively: Agriculture, climate change, and job creation in Africa. Agrekon, 57(3-4), 181-197.

https://doi.org/10.1080/03031853.2018.1538002

Canning, D., Raja, S., \& Yazbeck, A. S. (2015). Africa's Demographic Transition: Dividend or Disaster? Africa Development Forum, World Bank. http://hdl.handle.net/10986/22036

Casterline, J. B., \& Agyei-Mensah, S. (2017). Fertility Desires and the Course of Fertility Decline in sub-Saharan Africa. Population and Development Review, 43(S1), 84-111. https://doi.org/10.1111/padr.12030

Choudhry, M. T., \& Elhorst, P. (2018). Female labour force participation and economic development. International Journal of Manpower, 39(7), 896-912. https://doi.org/10.1108/IJM-03-2017-0045

Choudhry, M. T., Marelli, E., \& Signorelli, M. (2016). Age dependency and labour productivity divergence. Applied Economics, 48(50), 4823-4845.

https://doi.org/10.1080/00036846.2016.1167823

Cleland, J., \& Potter, J. E. (2019). Fertility Regulation. In Handbook of Population. Springer International Publishing. https://doi.org/10.1007/978-3-030-10910-3

Cummins, M. (2019). Population Dynamics and the Demographic Dividend Potential of Eastern and Southern Africa: A Primer (SSRN Scholarly Paper ID 3523552). Social Science Research Network. https://doi.org/10.2139/ssrn.3523552

Dancer, H., \& Hossain, N. (2017). Social Difference and Women's Empowerment in the Context of the Commercialisation of African Agriculture (p. 43) [APRA Working Paper]. Institute of Development Studies.

https://opendocs.ids.ac.uk/opendocs/bitstream/handle/20.500.12413/13558/APRA\%20W.P $\% 20$ number\%208.pdf? sequence=1\&isAllowed=y

Donehower, G. (2016). United Nations Expert Group Meeting on Changing Population Age Structures and Sustainable Development. United Nations. https://www.un.org/development/desa/pd/sites/www.un.org.development.desa.pd/files/201 610_egm_reportofthemeeting.pdf 
Eloundou-Enyegue, P., Giroux, S., \& Tenikue, M. (2017). African Transitions and Fertility Inequality: A Demographic Kuznets Hypothesis. Population and Development Review, 43(S1), 59-83. https://doi.org/10.1111/padr.12034

Eloundou-Enyegue, P. M., \& Hirschl, N. (2017). Fertility Transitions and Schooling Dividends in Sub-Saharan Africa: The Experience of Vanguard Countries. In H. Groth \& J. F. May (Eds.), Africa's Population: In Search of a Demographic Dividend (pp. 101-111). Springer International Publishing. https://doi.org/10.1007/978-3-319-46889-1_7

FAO. (2017). The future of food and agriculture - Trends and challenges. Food and Agriculture Organization of the United Nations. http://www.fao.org/3/a-i6583e.pdf

Filmer, D., \& Fox, L. (2014). Youth Employment in Sub-Saharan Africa (p. 283). Africa Development Forum, World Bank and Agence Française de Développement. http://hdl.handle.net/10986/16608

Finlay, J. E., Mejía-Guevara, I., \& Akachi, Y. (2018). Inequality in total fertility rates and the proximate determinants of fertility in 21 sub-Saharan African countries. PloS one, 13(9), e0203344. https://doi.org/10.1371/journal.pone.0203344

Fox, L., Haines, C., Munoz, J. H., Thomas, A. H.. (2013). Africa's Got Work to Do: Employment Prospects in the New Century. IMF Working Papers, 13(201), i. https://doi.org/10.5089/9781484389195.001

Fox, L., \& Thomas, A. (2016). Africa's Got Work To Do: A Diagnostic of Youth Employment Challenges in Sub-Saharan Africa. Journal of African Economies, 25(suppl_1), i16-i36. https://doi.org/10.1093/jae/ejv026

Frini, O., \& Jedidia, K. (2019). Population age structure change and labour productivity: Evidence from Tunisia. The European Journal of Applied Economics, 16(1), 1-19. https://doi.org/10.5937/EJAE15-18209

Gerland, P., Biddlecom, A., \& Kantorová, V. (2017). Patterns of Fertility Decline and the Impact of Alternative Scenarios of Future Fertility Change in sub-Saharan Africa. Population and Development Review, 43(S1), 21-38. https://doi.org/10.1111/padr.12011

Gori, L., \& Sodini, M. (2018). A contribution to the theory of fertility and economic development (Working Paper No. 170). GLO Discussion Paper. https://www.econstor.eu/handle/10419/173221

Groth, H., \& May, J. F. (Eds.). (2017). Africa's Population: In Search of a Demographic Dividend. Springer International Publishing. https://doi.org/10.1007/978-3-319-46889-1

Hanushek, E. A., \& Woessmann, L. (2012). Do better schools lead to more growth? Cognitive skills, economic outcomes, and causation. Journal of Economic Growth, 17(4), 267-321. https://doi.org/10.1007/s10887-012-9081-x

ILO. (2019). World Employment and Social Outlook: Trends 2019. International Labour Organization. https://www.ilo.org/global/research/global-reports/weso/2019/lang-en/index.htm 
Jayne, T., Yeboah, F. K., \& Henry, C. (2017). The future of work in African agriculture: Trends and drivers of change (Workign Paper No. 25; p. 42). International Labour Organization. https://www.ilo.org/wcmsp5/groups/public/---dgreports/--inst/documents/publication/wcms_624872.pdf

Karra, M., Canning, D., \& Wilde, J. (2017). The Effect of Fertility Decline on Economic Growth in Africa: A Macrosimulation Model. Population and Development Review, 43, 237-263. http://www.jstor.org/stable/26622881

Kenya National Council for Population and Development \& Health Policy Project (2014). Demographic Dividend Opportunities for Kenya. Results from the DemDiv model. Policy Brief for the Government of Kenya. https://www.healthpolicyproject.com/pubs/384_KenyaDemDivBrief.pdf

Kleven, H., \& Landais, C. (2017). Gender Inequality and Economic Development: Fertility, Education and Norms. Economica, 84(334), 180-209. https://doi.org/10.1111/ecca.12230

Lai, M. S. (2016). United Nations Expert Group Meeting on Changing Population Age Structures and Sustainable Development. United Nations.

https://www.un.org/development/desa/pd/sites/www.un.org.development.desa.pd/files/201 610_egm_reportofthemeeting.pdf

Lam, D., \& Leibbrandt, M. (2014). Youth Bulges and Youth Unemployment. Population Studies Center, University of Michigan. https://gsdrc.org/document-library/youth-bulges-and-youthunemployment/

Lam, D., Leibbrandt, M., \& Allen, J. (2019). The Demography of the Labor Force in Sub-Saharan Africa: Challenges and Opportunities. 10, 48. https://g2lm-lic.iza.org/publications/sp/sp10/

Lee, J., \& Newhouse, D. (2012). Cognitive Skills and Youth Labor Market Outcomes [Working Paper for World Development Report 2013]. World Bank.

http://hdl.handle.net/10986/12131

Lee, M., Patierno, K., \& Madsen, E. L. (2020). Investments in Family Planning and Education Drive Labor Productivity. Population Reference Bureau, USAID, PACE. prb-familyplanning-and-labor-market-policy-brief.pdf

Lee, R., \& Mason, A. (2010). Fertility, Human Capital, and Economic Growth over the Demographic Transition / Fécondité, capital humain et croissance économique au cours de la transition démographique. European Journal of Population / Revue Européenne de Démographie, 26(2), 159-182. http://www.jstor.org/stable/40784184

Losch, B. (2016). Structural transformation to boost youth labour demand in sub-Saharan Africa: The role of agriculture, rural areas and territorial development (Working Paper No. 204; p. 78). International Labour Organization. https://www.ilo.org/wcmsp5/groups/public/--ed_emp/documents/publication/wcms_533993.pdf

Lowder, S. K., Skoet, J., \& Raney, T. (2016). The Number, Size, and Distribution of Farms, Smallholder Farms, and Family Farms Worldwide. World Development, 87, 16-29. https://doi.org/10.1016/j.worlddev.2015.10.041 
Maghimbi, S. (2020). High Fertility is no Longer a Dividend: The Dynamics of a Big Young Population and Unemployment. Tanzania Journal for Population Studies and Development, 26(1), Article 1.

http://www.journals.udsm.ac.tz/index.php/tjpsd/article/view/3074

Mason, A., Lee, R., \& Jiang, J. X. (2016). Demographic Dividends, Human Capital, and Saving. The Journal of the Economics of Ageing, 7, 106-122. https://doi.org/10.1016/j.jeoa.2016.02.004

May, J. F., \& Turbat, V. (2017). The Demographic Divident in Sub-Saharan Africa: Two issues that need more attention. Journal of Demographic Economics, 83(1), 77-84. https://doi.org/10.1017/dem.2016.21

McCullough, E. B. (2017). Labor productivity and employment gaps in Sub-Saharan Africa. Food Policy, 67, 133-152. https://doi.org/10.1016/j.foodpol.2016.09.013

McKinsey Global Institute. (2017). A Future that Works: Automation, Employment, and Productivity. McKinsey \& Company.

https://www.mckinsey.com/ /media/mckinsey/featured\%20insights/Digital\%20Disruption/H arnessing\%20automation\%20for\%20a\%20future\%20that\%20works/MGI-A-future-thatworks-Executive-summary.ashx

Meagher, K. (2016). The Scramble for Africans: Demography, Globalisation and Africa's Informal Labour Markets. The Journal of Development Studies, 52(4), 483-497.

https://doi.org/10.1080/00220388.2015.1126253

Moreland, S., \& Madsen, E. L. (2017). Demographic Dividend Models. In H. Groth \& J. F. May (Eds.), Africa's Population: In Search of a Demographic Dividend (pp. 453-467). Springer International Publishing. https://doi.org/10.1007/978-3-319-46889-1_28

Moreland, S., Madsen, E. L., Kuang, B., Hamilton, M., \& Jurczynska, K. (2014). Modeling the Demographic Dividend: Technical Guide to the DemDiv Model. (p. 44). Health Policy Project and USAID.

http://www.healthpolicyproject.com/pubs/343_FINALDemDivTechnicalReportFINALEC.pdf

Nattrass, N., \& Seekings, J. (2018). Employment and labour productivity in high unemployment countries. Development Policy Review, 36(S2), 0769-0785.

https://doi.org/10.1111/dpr.12313

Newhouse, D., \& Wolff, C. (2014). Cohort Size and Youth Employment Outcomes [Policy Research Working Paper no.6848]. World Bank. http://hdl.handle.net/10986/18335

Phillips, N. J. (2016). Labour in Global Production: Reflections on Coxian Insights in a World of Global Value Chains. Globalizations, 13(5), 594-607. http://dx.doi.org/10.1080/14747731.2016.1138608

Pignatti, N. (2020). Encouraging women's labor force participation in transition countries. IZA World of Labor. http://wol.iza.org/articles/encouraging-womens-labor-force-participation-intransition-countries 
Population Council. (2020). Contributing to the Sustainable Development Goals by Investing in Adolescent girls and Young Women: Project Proposal to Danida.

https://www.google.com/url?sa=t\&rct=j\&q=\&esrc=s\&source=web\&cd=\&ved=2ahUKEwij15 6FyPvsAhV7QhUIHdEcCaAQFjAAegQIARAC\&url=https\%3A\%2F\%2Fum.dk\%2F \%2Fme dia\%2Fum\%2Fenglish-site\%2Fdocuments\%2Fdanida\%2Faboutdanida\%2Fdanida\%2520transparency\%2Fdocuments\%2Fu\%252037\%2F2020\%2Fpopula tion\%2520council.pdf\%3Fla\%3Den\&usg=AOvVaw0Y1pLmIn5TT8II5EW4Q5yK

Quak, E., \& Flynn, J. (2019). Private Sector Development Interventions and Better-Quality Job Creation for Youth in Africa. Institute of Development Studies. https://opendocs.ids.ac.uk/opendocs/handle/20.500.12413/14907

Quak, E., \& Tull, K. (2020). Evidence of successful interventions and policies to achieve a demographic transition in sub-Saharan Africa: Ethiopia, Rwanda, and Malawi. Institute of Development Studies. https://opendocs.ids.ac.uk/opendocs/handle/20.500.12413/15426

Quak, E., \& Woodhill, J. (2019). Capturing the economic potential of food systems for the poor. Institute of Development Studies.

https://opendocs.ids.ac.uk/opendocs/handle/20.500.12413/14555

Reardon, T., Echeverria, R., Berdegué, J., Minten, B., Liverpool-Tasie, S., Tschirley, D., \& Zilberman, D. (2019). Rapid transformation of food systems in developing regions: Highlighting the role of agricultural research \& innovations. Agricultural Systems, 172, 4759. https://doi.org/10.1016/j.agsy.2018.01.022

Rodrik, D. (2015). Premature Deindustrialization (No. w20935). National Bureau of Economic Research. https://doi.org/10.3386/w20935

Schultz, P. T. (2015). Fertility Transition: Economic Explanations. In J. D. Wright (Ed.), International Encyclopedia of the Social \& Behavioral Sciences (Second Edition) (pp. 6067). Elsevier. https://doi.org/10.1016/B978-0-08-097086-8.31076-5

Scott-Villiers, P., \& Kelbert, A. W. (2015). Introduction: How Prices Rose and Lives Changed. https://doi.org/10.1111/1759-5436.12181

Sjafii, A., Selvaratnam, D. P., Adib, M., \& Amini, N. W. (2016). Demographic transition and declining fertility rate: The labour productiy matter. Journal of Global Business and Social Entrepreneurship, 1(2), 54-62. http://gbse.com.my/isimarch16/GBSE\%201(2)\%205462\%20(March\%202016).pdf

Staatz, J., \& Hollinger, F. (2016). West African Food Systems and Changing Consumer Demands. https://doi.org/10.1787/b165522b-en

Stecklov, G., \& Menashe-Oren, A. (2019). IFAD Research Series 41: The Demography of Rural Youth in Developing Countries (SSRN Scholarly Paper ID 3567731). Social Science Research Network. https://doi.org/10.2139/ssrn.3567731

Sunmola, A. K., Olaosebikan, J. S., \& Adeusi, T. J. (2020). High fertility level in Sub-Saharan Africa: Implication for reaping and optimizing demographic dividend. International Journal 
Of Community Medicine And Public Health, 7(9), 3698-3704.

https://doi.org/10.18203/2394-6040.ijcmph20203947

Turbat, V. (2017). Economic Growth and Public and Private Investments. In H. Groth \& J. F. May (Eds.), Africa's Population: In Search of a Demographic Dividend (pp. 353-365). Springer International Publishing. https://doi.org/10.1007/978-3-319-46889-1_22

UN. (2013). National Transfer Accounts Manual: Measuring and Analysing the Generational Economy. United Nations, Population Division.

https://www.un.org/en/development/desa/population/publications/pdf/development/Final_M arch2014.pdf

UNDESA Population Division. (2019). World Population Prospects 2019: Highlights.

(ST/ESA/SER.A/423). UN DESA.

https://population.un.org/wpp/Publications/Files/WPP2019_Highlights.pdf

Van den Bold, M., Quisumbing, A. R., \& Gillespie, S. (2013). Women's Empowerment and Nutrition: An Evidence Review [IFPRI Discussion Paper 01294]. IFPRI.

https://papers.ssrn.com/sol3/papers.cfm?abstract_id=2343160

Wajnman, S. (2016). United Nations Expert Group Meeting on Changing Population Age Structures and Sustainable Development. United Nations.

https://www.un.org/development/desa/pd/sites/www.un.org.development.desa.pd/files/201

610_egm_reportofthemeeting.pdf

World Bank. (1984). World Development Report 1984. Recovery or Relapse in the World Economy? Population Change and Development; Population Data Supplement; World Development Indicators. World Bank. https://doi.org/10.1596/0-1952-0460-3

World Bank. (2016). World Development Report 2016: Digital Dividends [Text/HTML]. World Bank. https://www.worldbank.org/en/publication/wdr2016

Yeboah, F. K., \& Jayne, T. S. (2017). Africa's evolving employment trends: Implications for economic transformation. AfricaGrowth Agenda, 2017(Jan/Mar 2017), 18-22. https://journals.co.za/content/journal/10520/EJC-67c8c52c3 


\section{Acknowledgements}

I would like to thank the following experts who voluntarily provided suggestions for relevant literature or other advice to support the preparation of this report. The content of the report does not necessarily reflect the opinions of any of the experts consulted.

- Andrew Mason: Professor of the Department of Economics at the University of Hawaii, and founding director of the National Transfer Account Project.

- Elizabeth Leahy Madsen: Senior Programme Director for the International Programmes at the Population Reference Bureau (PRB).

- Joshua Wilde: Research Fellow in the Labour Demography Group at the Max Planck Institute for Demographic Research.

- Justin Flynn: Research Officer at the Institute of Development Studies (IDS) with a special interest on youth employment in sub-Saharan Africa.

\section{Suggested citation}

Quak, E. (2021). The link between demography and labour markets in sub-Saharan Africa. K4D Helpdesk Report No.911. Brighton, UK: Institute of Development Studies. DOI:

10.19088/K4D.2021.011

\section{About this report}

This report is based on twelve days of desk-based research. The K4D research helpdesk provides rapid syntheses of a selection of recent relevant literature and international expert thinking in response to specific questions relating to international development. For any enquiries, contact helpdesk@k4d.info.

K4D services are provided by a consortium of leading organisations working in international development, led by the Institute of Development Studies (IDS), with Education Development Trust, Itad, University of Leeds Nuffield Centre for International Health and Development, Liverpool School of Tropical Medicine (LSTM), University of Birmingham International Development Department (IDD) and the University of Manchester Humanitarian and Conflict Response Institute (HCRI).

This report was prepared for the UK Government's Foreign, Commonwealth and Development Office (FCDO) and its partners in support of pro-poor programmes. Except where otherwise stated, it is licensed for non-commercial purposes under the terms of the Open Government Licence v3.0. K4D cannot be held responsible for errors, omissions or any consequences arising from the use of information contained in this report. Any views and opinions expressed do not necessarily reflect those of FCDO, K4D or any other contributing organisation.

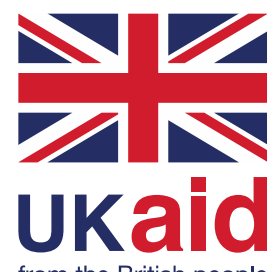

(C) Crown copyright 2021. 